\title{
KESULITAN SISWA DALAM PEMBELAJARAN MATEMATIKA DENGAN MENGGUNAKAN PENDEKATAN SAINTIFIK DITINJAU DARI KEMAMPUAN MATEMATIKA DI SMP
}

\author{
Akbar Taufik \\ Fakultas Keguruan dan Ilmu Pendidikan, Universitas Pancasakti Makassar \\ Jalan Andi Mangerangi No. 73, Makassar \\ Surel: akbartaufik@unpacti.ac.id
}

\begin{abstract}
Difficulties in Learning Mathematics by Using Scientific Approach Based on Students' Ability in SMP. The study aimed at describing the students' difficulties in learning Mathematics by using secientific approach based on students' Mathematics ability in SMPN 12 Makassar. This study was descriptive research with qualitative approach. The subjects were determined during data collecting process by considering several elements: students who had difficulties were observed directly during the learning process and showed no participation in scientific activities. The technique used to analyze the data was qualitative data analysis conducted interactively and continuously until it saturated forming patterns of data. The results of the study reveal that: (1) the basic difference of difficulties of students who have high Mathematics ability, medium Mathematics ability, and low Mathematics ability on the aspect of observing to understand Mathematics symbols: students with medium and low Mathematics abilities tend to unrecognized and acknowledge or able to read the symbols on the object observed, (2) the basic difference from the three subjects who have high Mathematics ability, medium Mathematics ability, and low Mathematics ability on the aspect of questioning is the level of questioning they make: students with high Mathematics ability tend to have the ability to ask questions higher in knowledge level compare to students with Mathematics medium ability which is merely able to ask questions in comprehension level; whereas, students with low Mathematics ability is completely unable to ask question, (3) the basic difference from the three subjects who have high Mathematics ability, medium Mathematics ability, and low Mathematics ability on the aspect collecting information and reasoning: students with medium and low mathematics abilities tend to have difficulties in completing the ask compare to students with high Mathematics ability, students with high Mathematics ability have no difficulty in completing the task, and (4) the basic difference from the three subjects who have high Mathematics ability, medium Mathematics ability, and low Mathematics abilityon the aspect og communicating: students with high and medium Mathematics abilities tend to be able to communicate their work result compare to the students who have low Mathematics ability which is completely unable to present their work result both in pictures and symbols.
\end{abstract}

\footnotetext{
Abstrak: Kesulitan Siswa Dalam Pembelajaran Matematika Dengan Menggunakan Pendekatan Saintifik Ditinjau Dari Kemampuan Matematika di SMP. Penelitian ini bertujuan untuk mendeskripsikan kesulitan siswa dalam pembelajaran matematika dengan menggunakan pendekatan saintifik ditinjau dari kemampuan matematika di SMP Negeri 12 Makassar. Jenis penelitian ini adalah penelitian deskriptif dengan pendekatan kualitatif. Subjek ditentukan selam proses pengumpulan data, dengan mempertimbangkan beberapa hal seperti: siswa yang mengalami kesulitan diamati pada saat pembelajaran berlangsung yang menunjukkan prilaku tidak berpartisipasi dalam kegiatan saintifik. Teknik analisis data yang digunakan adalah analisis data kualitatif yang dilakukan secara interaktif dan berlangsung secara terus menerus sampai tuntas, sehingga membentuk data yang berpola. Hasil penelitian menunjukkan bahwa: (1) Perbedaan mendasar kesulitan dari siswa yang berkemampuan matematika tinggi, sedang dan rendah dalam aspek mengamati adalah kemampuan dalam memahami simbol-simbol matematika, siswa berkemampuan sedang dan rendah cenderung tidak mengetahui dan mengenal atau bisa membaca simbol-simbol yang ada pada objek yang mereka amati (2) Perbedaan mendasar dari ketiga subjek berkemampuan matematika tinggi, sedang dan rendah dalam aspek menanya adalah level atau tingkatan pertanyaan yang mereka ajukan. Siswa berkemampuan matematika tinggi cenderung lebih bisa mengajukan pertanyaan lebih tinggi di tingkat pengetahuan dibanding dengan siswa berkamampuan matematika sedang yang hanya bisa mengajukan pertanyan di
} 
tingkat pertanyaan pemahaman, sedangkan siswa berkemampuan matematika rendah sama sekali tidak bisa mengajukan sebuah pertanyaan.(3) Perbedaan mendasar dari ketiga subjek berkemampuan matematika tinggi, sedang dan rendah dalam aspek mengumpulkan informasi dan menalar adalah siswa berkemapuan matematika sedang dan rendah cenderung lebih sulit dalam mengerjakan dan menyelesaikan soal latihan dibanding dengan siswa berkemampuan matematika tinggi. Siswa berkemampuan matematika tinggi tidak mengalami masalah dalam mengerjakan soal latihan yang diberikan.(4) Perbedaan mendasar dari ketiga subjek berkemampuan matematika tinggi, sedang dan rendah dalam aspek mengkomunikasikan adalah siswa berkemampuan matematika tinggi dan sedang cenderung lebih bisa dalam mengkomunikasikan hasil pekerjaannya dibanding dengan siswa berkemampuan matematika rendah yang tidak bisa sama sekali untuk menyajikan hasil pekerjaannnya baik itu berupa gambar maupun simbol-simbol.

\section{Kata Kunci: Kesulitan Siswa, Pendekatan Saintifik, Matematika}

\section{PENDAHULUAN}

Pendidikan memberikan kemungkinan pada siswa untuk memperoleh kesempatan, harapan dan pengetahuan agar dapat hidup secara lebih baik. Pendidikan yang berkualitas tentunya melibatkan siswa untuk aktif belajar dan mengarahkan terbentuknya nilai-nilai yang dibutuhkan oleh siswa dalam menempuh kehidupan, pendidikan juga menuntut guru untuk bagaimana membangun interaksi yang baik dengan peserta didik. Dalam interaksi di kelas, guru menjadi pusat perhatian dari para peserta didik. Mulai dari penampilan, kemampuan mengajar, sikap, kedisiplinan mengajar serta hal-hal kecil yang terkadang lepas dari perhatian guru pun dapat menjadi objek penilaian peserta didik terhadap gurunya. Tak jarang, peserta didik melakukan peniruan terhadap kebiasaan atau pola pikir dari gurunya itu.

Hal ini sesuai dengan pendapat Soejadi (Rusli, 2006) yang mengemukakan bahwa satu-satunya wadah kegiatan yang dapat dipandang dan dapat berfungsi sebagai sumber daya manusia bermutu tinggi adalah pendidikan, baik itu melalui jalur sekolah maupun di luar sekolah. Menyadari akan pentingnya peningkatan kulitas pendidikan sebagai upaya peningkatan sumber daya manusia maka pendidikan kita ke depan harus mendapatkan sentuhan pengembangan yang lebih serius. Pembaharuan pendidikan dan pembelajaran selalu dilaksanakan dari waktu ke waktu dan tak pernah henti. Pendidikan dan pembelajaran berbasis karakter merupakan contoh hasil perubahan dengan tujuan untuk meningkatkan kualitas pendidikan dan pembelajaran.

Implementasi kurikulum 2013 yang dikenal dengan pembelajaran berbasis karakter diarahkan untuk memberdayakan semua potensi yang dimiliki peserta didik agar mereka dapat memiliki kompetensi yang diharapkan melalui upaya menumbuhkan serta mengembangkan; sikap/attitude, pengetahuan/knowledge, dan keterampilan/skill. Kualitas lain yang dikembangkan kurikulum dan harus terealisasikan dalam proses pembelajaran, antaralain kreativitas, kemandirian, kerja sama, solidaritas, kepemimpinan, empati, toleransi dan kecakapan hidup peserta didik guna membentuk watak serta meningkatkan peradaban dan martabat bangsa (Hosnan, 2014).

Proses pembelajaran dalam kurikulum 2013 peran guru harus bergeser menjadi perancang pembelajaran agar siswa aktif mencari pengetahuan baru dan sebagai fasilitator bagi siswa untuk belajar. Guru seharusnya menyadari pentingnya membentuk nilai-nilai penting dalam diri siswa sehingga ingin melakukakan inovasi dalam proses belajar-mengajar, sehingga siswa bisa lebih aktif dan terlibat langsung didalamnya. Didalam kurikulum 2013, salah satu pendekatan yang ditekankan adalah pendekatan saintifik, penerapan pembelajaran dengan pendekatan saintifik memungkinkan siswa untuk memperoleh nilai-nilai penting pembelajaran.

Proses belajar secara saintifik mencakup beberapa aktifitas, diantaranya: mengajukan pertanyaan, melakukan pengamatan (observasi), melakukan penalaran, melakukan eksperimentasi atau mencoba, mengembangkan jaringan (Sani, 2014). Pendekatan saintifik adalah proses pembelajaran yang dirancang sedemikian rupa agar peserta didik secara aktif mengkonstruk konsep, hukum atau prinsip melalui tahapan- 
tahapan mengamati (untuk mengidentifikasi atau menemuka masalah), merumuskan masalah, mengajukan atau merumuskan hipotesis, mengumpulkan data dengan berbagai teknik, menganalisis data, menarik kesimpulan dan mengkomunikasikan konsep, hukum atau prinsip yang ditemukan (Hosnan, 2014).

Pembelajaran matematika dengan Pendekatan Saintifik telah dilaksanakan di SMP Negeri 12 Makassar di kelas VIII sejak semester II tahun ajaran 2013/2014. Guru-guru matematika yang melaksanakan pembelajaran dengan Pendekatan Saintifik adalah guru-guru yang telah mengikuti Pelatihan Kurikulum 2013 khususnya pelatihan Pendekatan Saintifik. Penerapan Pendekatan Saintifik dalam pembelajaran matematika di SMP Negeri 12 Makassar telah dilaksanakan dalam berbagai model pembelajaran seperti proyek matematika, pembelajaran berbasis masalah, dan model inquiri dan telah terlaksana dengan baik. Namun demikian pengamatan penulis di sekolah, menemukan gejala adanya kesulitan siswa dalam aktivitas pembelajaran dengan pendekatan saintifik. Beberapa diantaranya adalah sulitnya siswa dalam mengamati objekobjek ataupun bentuk soal yang diberikan, mengajukan pertanyaan, serta dalam menyampaikan kesimpulan dari apa yang telah mereka pelajari.

Kesulitan belajar matematika disebut

juga diskalkulia (dyscalculia). Istilah diskalkulia memiliki konotasi medis yang memandang adanya keterkaitan dengan gangguan sistem syaraf pusat (Lerner dalam Abdurrahman, 2012). Menurut Mulyadi kesulitan belajar mempunyai pengertian yang luas dan kedalamannya termasuk pengertianpengertian seperti: (a) Learning Disorder (Ketergangguang Belajar) Adalah keadaan di mana proses belajar seseorang terganggu karena timbulnya respons yang bertentangan (b) Learning Disabilities (Ketidakmampuan Belajar) Adalah ketidakmampuan seseorang murid yang mengacu kepada gejala di mana murid tidak mampu belajar (menghindari belajar) sehingga hasil belajarnya di bawah potensi intelektualnya. (c) Under Achiever (Pencapaian Rendah) Adalah mengacu kepada murid-murid yang memilki tingkat potensi intelektual di atas normal, tetapi potensi belajarnya tegolong rendah. (d) Slow Learner (Lambat Belajar) Adalah murid yang lambat belajar dalam proses belajarnya sehingga membutuhkan waktu dibandingkan dengan murid-murid yang lain yang memiliki taraf potensi intelektual yang sama.

Tujuan dalam penelitian ini adalah untuk mengetahui deskripsi kesulitan siswa dalam pembelajaran matematika dengan menggunakan pendekatan saintifik ditinjau dari kemampuan matematika di SMP Negeri 12 Makassar.

\section{METODE}

Penelitian ini termasuk penelitian deskriptif dengan pendekatan kualitatif. Adapun Subjek dalam penelitian ini adalah siswa kelas VII-7 di SMPN 2 Makassar. Selanjutnya dipilih satu orang yang berkemampuan matematika tinggi, sedang, dan rendah sebagai subjek yang di teliti yang diperoleh dari nilai rapor semester ganjil 2015/2016 dengan pertimbangan siswa tersebut teridentifikasi menunjukkan prilakuprilaku kesulitan dalam pembelajaran matematika dengan menggunakan pendekatan saintifik.

Instrumen yang digunakan, yaitu instrumen utama adalah peneliti itu sendiri dan instrumen pendukung. Instrumen pendukung sebagai alat pengumpul data yang digunakan peneliti adalah lembar observasi pengamatan aktivitas siswa dan pedoman wawancara.

Analisis data dalam penelitian ini didahului proses reduksi data disusul dengan penyajian data dan diakhiri dengan penarikan kesimpulan dari hasil analisis.

\section{HASIL DAN PEMBAHASAN HASIL}

Tahapan pertama yang dilakukan dalam proses penelitian adalah tahap persiapan yaitu observasi lapangan dengan tujuan untuk menentukan calon subjek penelitian. Subjek dalam penelitian ini adalah siswa kelas VII-7 SMPN 12 Makassar yang berkemampuan matematika tinggi, sedang dan rendah. Selanjutnya dipilih satu orang dari masingmasing tingkatan kemampuan dengan syarat siswa tersebut mengalami kesulitan dalam pembelajaran matematika dengan menggunakan pendekatan saintifik yang ditunjukkan dengan prilaku-prilaku kesulitan yang diperoleh melalui pengamatan yang kemudian dicatat di lembar observasi.

Untuk memperoleh data yang valid, dalam penelitian ini menggunakan beberapa instrumen untuk melihat kesulitan siswa dalam pemebelajaran matematika dengan 
menggunakan pendekatan saintifik. Dalam penelitian ini digunakan instrumen, yang terdiri dari instrumen utama dan instrumen pendukung. Instrumen yang digunakan dalam penelitian ini terlebih dahulu divalidasi oleh dua pakar pendidikan matematika agar diperoleh instrumen yang valid.

1. Paparan Data Siswa yang Mengalami Kesulitan Dalam Pendekatan Saintifik (Aspek Mengamati)

a. Paparan Data Hasil Penelitian pada Subjek Berkemampuan Matematika Tinggi (MT1)

Subjek menyatakan bahwa bahasa yang digunakan pada soal/objek yang diamati terlalu rumit ntuk langsung dimengerti (DV MT - 001 -01) hal ini ditunjukkan dengan pernyataan subjek yang mengatakan bahwa ia harus membaca berulang-ulang (A002) soal tersebut hingga ia bisa memahami apa yang akan ia amati.

Dari analisis diatas dapat disimpulkan bahwa kesulitan siswa berkemampuan matematika tinggi dalam mengamati adalah kurangnya pemahaman dan penguasaan siswa terhadap bahasa yang digunakan pada soal/objek yang diamati.

b. Paparan Data Hasil Penelitian pada Subjek Berkemampuan Matematika Sedang (MS1)

Subjek menyatakan bahwa subjek tidak paham terhadap simbol yang ada pada objek/soal yang diamati (DV MS - 001 - 01). Hal ini ditunjukkan dengan tidak bisanya subjek membaca hasil bayangan dari proses translasi.

Subjek menyatakan bahwa bahasa yang digunakan pada soal/objek yang diamati terlalu rumit ntuk langsung dimengerti (DV MS - 001 -02) hal ini ditunjukkan dengan pernyataan subjek yang mengatakan bahwa ia harus bertanya ke temannya hingga ia bisa memahami apa yang akan ia amati (E002,E101).

Dari analisis diatas dapat disimpulkan bahwa kesulitan siswa berkemampuan matematika sedang dalam mengamati adalah kurangnya pemahaman siswa terhadap simbol-simbol matematika dan kurangnya pemahaman dan penguasaan siswa terhadap bahasa yang digunakan pada soal/objek yang diamati.

c. Paparan Data Hasil Penelitian pada Subjek Berkemampuan Matematika Rendah (MR1)

Subjek menyatakan bahwa subjek tidak tertarik terhadap mata pelajaran matematika (DV MR - $001-01)$. Hal ini ditunjukkan dengan prilaku subjek dengan berpindah-pindah tempat duduk (K001,K101) dan kemudian subjek tidak mengerjakan apa-apa (K102).

Subjek menyatakan bahwa subjek tidak memahami dan mengerti materi yang akan diamati (DV MR - 001 - 02). Hal ini ditunjukkan dengan tidak bisanya subjek menjelaskan apa yang ia amati.

Subjek menyatakan bahwa ia tidak tahu dengan simbol dan gambar yang ia amati (DV MR - 001 -03). Hal ini ditunjukkan dengan pernyataan subjek yang tidak mengetahui simbol dan gambar yang ada pada objek/soal yang diamati

Dari analisis diatas dapat disimpulkan bahwa kesulitan siswa berkemampuan matematika rendah dalam mengamati adalah kurangnya minat siswa terhadap mata pelajaran matematika, kemudian kurangnya pemahaman siswa terhadap materi yang ia amati dan kurangnya pemahaman siswa terhadap simbolsimbol dan gambar dalam matematika.

2. Paparan Data Siswa yang Mengalami Kesulitan Dalam Pendekatan Saintifik (Aspek Menanya)

a. Paparan Data Hasil Penelitian pada Subjek Berkemampuan Matematika Tinggi (MT2)

Subjek menyatakan bahwa subjek merasa malu, ragu dan takut untuk bertanya (DV MT - 002 - 01). Hal ini ditunjukkan dengan subjek tidak mengajukan pertanyaan pada pertemuan pertama yang kemudian pada wawancara yang dilakukan subjek mengatakan bahwa ia malu dan ragu sehingga ia tidak percaya diri untuk mengajukan pertanyaan.

Subjek mengajukan pertanyaan pada level pertanyaan pemahaman (DV MT 001 - 01) hal ini ditelusuri melalui wawancara dimana subjek hanya bisa mengajukan sebuah pertanyaan pada level pemahaman namun demikian 
pertanyaan yang subjek ajukan sudah berhubungan dengan materi yang sedang dibahas (B101).

Dari analisis diatas dapat disimpulkan bahwa kesulitan siswa berkemampuan matematika tinggi dalam menanya adalah kurangnya rasa percaya diri siswa dalam mengajukan pertanyaan, dan kurangnya tingkat kedalaman materi siswa sehingga hanya bisa mengajukan pertanyaan di level pemahaman.

b. Paparan Data Hasil Penelitian pada Subjek Berkemampuan Matematika Sedang (MS2)

Subjek mengajukan pertanyaan pada level pertanyaan pengetahuan (DV MS 002 - 01) hal ini ditelusuri melalui wawancara dimana subjek hanya bisa mengajukan sebuah pertanyaan pada level pengetahuan namun demikian pertanyaan yang subjek ajukan sudah berhubungan dengan materi yang sedang dibahas (F102).

Subjek menyatakan bahwa subjek merasa malu, ragu dan takut untuk bertanya (DV MT - $002-01$ ). Hal ini ditunjukkan dengan subjek tidak mengajukan pertanyaan pada pertemuan pertama yang kemudian pada wawancara yang dilakukan subjek mengatakan bahwa ia malu dan ragu sehingga ia tidak percaya diri untuk mengajukan pertanyaan juga terlihat pada pertemuan kedua dimana subjek telihat ragu-ragu ketika mengacungkan tangannya untuk bertanya (F101).

Dari analisis diatas dapat disimpulkan bahwa kesulitan siswa berkemampuan matematika sedang dalam menanya adalah kurangnya tingkat kedalaman materi siswa sehingga hanya bisa mengajukan pertanyaan di level pengetahuan dan kurangnya rasa percaya diri siswa dalam mengajukan pertanyaan.

c. Paparan Data Hasil Penelitian pada Subjek Berkemampuan Matematika Rendah (MR2)

Subjek menyatakan bahwa tidak paham dengan materi yang diajarkan sehingga ia tidak bertanya (DV MR - $002-01$ ). Hal ini ditunjukkan dengan subjek tidak mengajukan pertanyaan pada pertemuan pertama dan pertemuan kedua (L001,L101).

Subjek sulit dalam membuat pertanyaan (DV MR -002 - 02) hal ini ditelusuri melalui wawancara dimana subjek menyataka ia tidak bertanya karean subjek tidak bisa membuat dan menyusun sebuah pertanyaan yang bagus.

Dari analisis diatas dapat disimpulkan bahwa kesulitan siswa berkemampuan matematika rendah dalam menanya adalah siswa tidak menguasai materi pembelajaran yang diajarkan dan siswa sulit dalam membuat sebuah kalimat pertanyaan.

3. Paparan Data Siswa yang Mengalami Kesulitan (Apek Mengumpulkan informasi dan menalar)

a. Paparan Data Hasil Penelitian pada Subjek Berkemampuan Matematika Tinggi (MT3)

Subjek menyatakan bahwa ia hanya mempunyai satu bahan referensi/buku yang ia gunakan dalam mengumpulkan informasi (DV-MT-003-01). Hal ini juga terlihat pada saat pengamatan yakni (C101) siswa hanya mempunyai satu bahan bacaan/referensi.

Dari analisis diatas dapat disimpulkan bahwa kesulitan siswa berkemampuan matematika tinggi dalam mengumpulkan informasi dan menalar adalah kurangnya bahan bacaan/referensi yang bisa digunakan dalam mengumpulkan informasi namun siswa berkemampuan tinggi tidak mengalami kesulitan dalam menalar.

b. Paparan Data Hasil Penelitian pada Subjek Berkemampuan Matematika Sedang (MS3)

Subjek menyatakan bahwa ia hanya mempunyai satu bahan referensi/buku yang ia gunakan dalam mengumpulkan informasi (DV-MS-003-01). Hal ini juga terlihat pada saat pengamatan yakni (G101) siswa hanya mempunyai satu bahan bacaan/referensi. Ini menunjukkan bahwa informasi yang siswa peroleh sangat sedikit yang hanya terbatas pada satu buku pegangan saja.

Subjek menyatakan tidak tahu cara mengerjakan soal yang diberikan (DV MS - 003 -02). Hal ini teramati dengan seringnya subjek bertanya dan melihat 
pekerjaan temannya (G003,G103). Ini menunjukkan bahwa pemahaman subjek terhadap materi sangat kurang sehingga subjek harus melihat pekerjaan temannya dan tidak mengerjakan soal itu sendiri.

Subjek menyatakan belum bisa menerapkan rumus-rumus pada materi translasi dan refleksi (DV MS - 003 03). Ini juga menandakan bahwa pemahaman subjek dan penerapan informasi yang subjek ketahui masih sangat kurang dengan tidak bisanya subjek dalam menerapkan rumus-rumus translasi dan refleksi yang ia ketahui Dari analisis diatas dapat disimpulkan bahwa kesulitan siswa berkemampuan matematika sedang dalam mengumpulkan informasi dan menalar adalah kurangnya bahan bacaan/referensi yang bisa digunakan dalam mengumpulkan informasi, kemudian kesulitan dalam pemahaman terhadap proses pengerjaan soal, dan kesulitan dalam menerapkan rumusrumus matematika.

c. Paparan Data Hasil Penelitian pada Subjek Berkemampuan Matematika Rendah (MR3)

Subjek menyatakan bahwa ia tidak mempunyai bahan referensi/buku yang ia gunakan dalam mengumpulkan informasi (DV-MR-003-01). Hal ini juga terlihat pada saat pengamatan yakni (M101) siswa tidak mempunyai bahan bacaan/referensi. Ini menunjukkan bahwa pengetahuan siswa tentang informasi-informasi yang terkait dengan materi dan soal yang akan ia kerjakan sangat sedikit.

Subjek menyatakan tidak paham cara mengerjakan soal yang diberikan (DV MR - 003 -02). Hal ini teramati dengan seringnya subjek berkeliaran di kelas dan melihat pekerjaan temannya (M102,M103). Ini menunjukkan bahwa pemahaman subjek terhadap materi sangat kurang sehingga subjek harus melihat pekerjaan temannya dan tidak mengerjakan soal itu sendiri.

Subjek menyatakan tidak tahu menerapkan rumus-rumus pada materi translasi dan refleksi (DV MR - 003 03). Ini juga menandakan bahwa pemahaman subjek dan penerapan informasi yang subjek ketahui masih sangat kurang dengan tidak bisanya subjek dalam menerapkan rumus-rumus translasi dan refleksi.

Subjek kesulitan dalam menarik kesimpulan (DV MR-003-04). Ini menunjukkan bahwa subjek kesulitan dalam menginterpretasi informasiinformasi yang telah ia peroleh selama proses pembelajaran

Dari analisis diatas dapat disimpulkan bahwa kesulitan siswa berkemampuan matematika rendah dalam mengumpulkan informasi dan menalar adalah tidak adanya bahan bacaan/referensi yang bisa digunakan dalam mengumpulkan informasi, kemudian kesulitan dalam pemahaman terhadap proses pengerjaan soal, kesulitan dalam menerapkan rumusrumus matematika dan kesulitan dalam menginterpretasi informasi-informasi yang telah diperoleh.

4. Paparan Data Siswa yang Mengalami Kesulitan (Aspek Mengkomunikasikan)

a. Paparan Data Hasil Penelitian pada Subjek Berkemampuan Matematika Tinggi (MT4)

Subjek menyatakan bahwa ia tidak terbiasa untuk mengerjakan hasil pekerjaannya di papan tulis (DV-MT004-01). Hal ini juga terlihat pada saat pengamatan yakni (D101) siswa sering menoleh dan bertanya ke temannya. Ini menunjukkan bahwa siswa tersebut kesulitan dalam menyajikan hasil pekerjaannya dan mentrasfer pengetahuannya.

Subjek menyatakan konsentrasinya sering terganggu saat mengerjakan di papn tulis (DV MT-004-02). Hal ini menunjukkan bahwa siswa tidak terbiasa dalam menyampaikan dan menyajikan hasil pekerjaannya di papan tulis maupun secara lisan.

Dari analisis diatas dapat disimpulkan bahwa kesulitan siswa berkemampuan matematika tinggi dalam mengkomunikasikan adalah kesulitan dalam menyampaikan dan mentransfer pengetahuannya.

b. Paparan Data Hasil Penelitian pada Subjek Berkemampuan Matematika Sedang (MS4) 
Subjek menyatakan bahwa subjek tidak bisa mengutarakan hasil pekerjaannya (DV MS-004-01). Hal ini ditunjukkan dalam pengamatan yakni (H101) siswa terbata-bata dalam menyampaikan hasil pekerjaannya. Hak ini menunjukkan bahwa siswa tersebut kesulitan dalam menyajikan dan menyampaikan pengetahuannya

Dari analisis diatas dapat disimpulkan bahwa kesulitan siswa berkemampuan matematika sedang dalam mengkomunikasikan adalah kesulitan dalam mentransfer pengetahuan.

c. Paparan Data Hasil Penelitian pada Subjek Berkemampuan Matematika Rendah (MR4)

Subjek menyatakan bahwa ia sulit untuk menjelaskan hasil pekerjaannya (DVMR-004-01). Hal ini juga terlihat pada saat pengamatan yakni (N101) siswa tidak mengerjakan hasil pekerjaannya di papan tulis, ini menunjukkan bahwa siswa tersebut tidak bisa menyampaikan hasil pekerjaanya.

Subjek menyatakan tidak tahu cara menggambarkan titik-titik koordinat dan membaca simbol (DV MR-004-02). Ini menunjukkan bahwa kurangnya pengetahuan subjek tentang gambar dan simbol-simbol dalam matematika.

Dari analisis diatas dapat disimpulkan bahwa kesulitan siswa berkemampuan matematika rendah dalam mengkomunikasikan adalah siswa sulit dalam menyajikan dan menyampaikan hasil pekerjaannya baik itu berupa gambar maupun berupa simbol.

\section{PEMBAHASAN}

\section{Deskripsi Kesulitan Siswa dalam Pembelajaran Matematika dengan Pendekatan Saintifik Aspek Mengamati Ditinjau Dari Kemampuan Matematikanya}

Berdasarkan hasil wawancara subjek menjelaskan bahwa kesulitan dalam pendekatan saintifik langkah mengamati adalah siswa tidak paham dengan masalah yang diberikan dan sulit untuk memaknai maksud dari masalah tersebut. Dalam proses pembelajaran yang terjadi di lapangan guru sama sekali tidak memberikan penjelasan kepada siswanya sehingga siswa bingung dan sulit dalam memahami dan memaknai apa yang mereka amati. Kesulitan siswa dalam pendekatan saintifik langkah mengamati adalah subjek tidak memahami/mengerti dengan bahasa, gambar, dan simbol-simbol matematika yang ada dalam masalah yang diberikan. Menurut Lerner (dalam Abdurrahman, 2012) Hal ini sesuai dengan karakteristik anak yang berkesulitan belajar matematika yang sering mengalami kesulitan dalam mengenal dan menggunakan simbol-simbol matematika seperti (+), (-), (x), (:), (=), (<), $(>)$, gangguan ini dapat disebabkan oleh gangguan memori, dan oleh gangguan persepsi visual.

2. Deskripsi Kesulitan Siswa dalam Pembelajaran Matematika dengan Pendekatan Saintifik Aspek Menanya Ditinjau Dari Kemampuan Matematikanya

Kesulitan siswa dalam pendekatan saintifik langkah menanya adalah siswa tidak paham dengan materi yang akan ditanyakan sehingga siswa tidak dapat membuat atau menyusun sebuah pertanyaan. Hal ini juga disebabkan karena kurangnya bimbingan guru dalam proses pembelajaran di kelas sehingga siswa-siswa kurang tertantang untuk mengajukan pertanyaan.

Kemudian kurangnya rasa percaya diri siswa dalam mengugkapkan pertanyaannya, siswa kurang diberikan stimulus dalam membuat pertanyaan sehingga siswa tersebut tidak mempunyai rasa percaya diri dalam mengajukan dan membuat sebuah pertanyaan dan lebih memilih bertanya ke temannya sendiri dibanding bertanya ke guru

3. Deskripsi Kesulitan Siswa dalam Pembelajaran Matematika dengan Pendekatan Saintifik Aspek Mengumpulkan informasi dan Menalar Ditinjau Dari Kemampuan Matematikanya

Kesulitan siswa dalam pendekatan saintifik langkah mengumpulkan informasi dan menalar adalah kurangnya fasilitas yang dimilki oleh siswa maupun fasilitas yang disediakan di sekolah baik itu berupa buku bacaan maupun alat-alat peraga.

Kemudian kesulitan yang selanjutnya adalah siswa sulit dan tidak terbiasa untuk mengkonstruk pengetahuannya sendiri sehingga setelah dihadapkan dengan soal dia akhirnya kesulitan untuk 
mengerjakannya hal ini sesuai dengan pendapat Kirk dan Gallagher (dalam Jamaris, 2014) yaitu kesulitan berpikir kemampuan dalam mengoperasikan kemampuan kognitif yang mencakup kemampuan memformasikan konsep dan mengasosiasikan formasi konsep dalam memecahkan masalah.

4. Deskripsi Kesulitan Siswa dalam Pembelajaran Matematika dengan Pendekatan Saintifik Aspek Mengkomunikasikan Ditinjau Dari Kemampuan Matematikanya

Kesulitan siswa dalam pendekatan saintifik langkah mengkomunikasikan adalah siswa cenderung sulit untuk mengkomunikasikan atau mentransfer pengetahuan mereka karena mereka malu-malu, takut, dan raguragu untuk menyampaikan pendapat mereka. Mereka tidak terbiasa dalam menyampaikan pendapat di depan umum.

Siswa juga sring terganggu dan kadang tidak konsentrasi dalam mengerjakan di papan tulis karena suasana kelas yang ribut. Hal ini jika sesuai dengan pendapat Kirk dan Gallagher (dalam Jamaris) yang menyatakan bahwa kesulitan dalam memusatkan perhatian dapat menghambart proses belajar.

Kemudian siswa juga kesulitan dalam menyajikan hasil pekerjaan mereka kedalam bentuk gambar hal ini sesuai pendapat learner (dalam Abdurrahman, 2012) yaitu abnormalitas persepsi visual dimana anak berkesulitan belajar matematika sering mengalami kesulitan untuk melihat berbagai objek dalam hubungannya dengan kelompok dimana dalam hal ini siswa sulit untuk menggambarkan bentuk geometri yang telah ditentukan titik-titik koordinatnya.

5. Perbedaan Kesulitan Siswa Dalam Pembelajaran Matematika Dengan Menggunakan Pendekatan Saintifik Ditinjau Dari Kemampuan Belajar

a. Aspek Mengamati

Perbedaan mendasar dari siswa yang berkemampuan matematika tinggi, sedang dan rendah dalam aspek mengamati adalah kemampuan dalam memahami simbol-simbol matematika, siswa berkemampuan sedang dan rendah cenderung tidak mengetahui dan mengenal atau bisa membaca simbol- simbol yang ada pada objek yang mereka amati.

Mereka kesulitan apabila mengamati objek yang terdapat simbol-simbol matematika didalamnya mereka sulit untuk membacanya dan bahkan siswa berkemampuan matematika rendah tidak tahu nama dari simbol-simbol yang ada pada objek yang diamati tersebut.

b. Aspek Menanya

Perbedaan mendasar dari ketiga subjek berkemampuan matematika tinggi, sedang dan rendah dalam aspek menanya adalah level atau tingkatan pertanyaan yang mereka ajukan. Siswa berkemampuan matematika tinggi cenderung lebih bisa mengajukan pertanyaan lebih tinggi di tingkat pengetahuan dibanding dengan siswa berkamampuan matematika sedang yang hanya bisa mengajukan pertanyan di tingkat pertanyaan pemahaman, sedangkan siswa berkemampuan matematika rendah sama sekali tidak bisa mengajukan sebuah pertanyaan.

c. Aspek Mengumpulkan Informasi dan Menalar

Perbedaan mendasar dari ketiga subjek berkemampuan matematika tinggi, sedang dan rendah dalam aspek mengumpulkan informasi dan menalar adalah siswa berkemapuan matematika sedang dan rendah cenderung lebih sulit dalam mengerjakan dan menyelesaikan soal latihan dibanding dengan siswa berkemampuan matematika tinggi. Siswa berkemampuan matematika tinggi tidak mengalami masalah dalam mengerjakan soal latihan yang diberikan.

d. Aspek Mengkomunikasikan

Perbedaan mendasar dari ketiga subjek berkemampuan matematika tinggi, sedang dan rendah dalam aspek mengkomunikasikan adalah siswa berkemampuan matematika tinggi dan sedang cenderung lebih bisa dalam mengkomunikasikan hasil pekerjaannya dibanding dengan siswa berkemampuan matematika rendah yang tidak bisa sama sekali untuk menyajikan hasil pekerjaannnya baik itu berupa gambar maupun simbol-simbol. 


\section{SIMPULAN}

Berdasarkan hasil penelitian dan pembahasan, maka dapat disimpulkan hal-hal sebagai berikut:

1. Aspek Mengamati

a. Siswa berkemampuan matematika tinggi kesulitan dalam memahami bahasa yang digunakan pada soal/objek yang diamati.

b. Siswa berkemampuan matematika sedang kesulitan dalam memahami simbol-simbol matematika dan mengerti terhadap bahasa yang digunakan pada soal/objek yang diamati.

c. Siswa berkemampuan matematika rendah kesulitan dalam memahami dan mengerti materi yang disajikan, tidak memahami simbol-simbol dan gambar dalam matematika, dan kurangnya minat terhadap mata pelajaran matematika

2. Aspek Menanya

a. Kesulitan siswa berkemampuan matematika tinggi adalah kuarangnya rasa percaya diri dalam menanya dan kurangnya tingkat kedalaman materi siswa sehingga hanya bisa mengajukan pertanyaan di level pemahaman.

b. Kesulitan siswa berkemampuan matematika sedang adalah kurangnya tingkat kedalaman materi siswa sehingga hanya bisa mengajukan pertanyaan di level pengetahuan dan kurangnya rasa percaya diri siswa dalam mengajukan pertanyaan.

c. Kesulitan siswa berkemampuan matematika rendah adalah siswa tidak menguasai materi pembelajaran yang diajarkan dan siswa sulit dalam membuat sebuah kalimat pertanyaan.

3. Aspek Mengumpulkan Informasi dan Menalar

a. Kesulitan siswa berkemampuan matematika tinggi adalah kurangnya bahan bacaan/referensi yang bisa digunakan dalam mengumpulkan informasi namun siswa berkemampuan tinggi tidak mengalami kesulitan dalam menalar.

b. Kesulitan siswa berkemampuan matematika sedang adalah kurangnya bahan bacaan/referensi yang bisa digunakan dalam mengumpulkan informasi, kemudian kesulitan dalam pemahaman terhadap proses pengerjaan soal, dan kesulitan dalam menerapkan rumus-rumus matematika.

c. Kesulitan siswa berkemampuan matematika rendah adalah tidak adanya bahan bacaan/referensi yang bisa digunakan dalam mengumpulkan informasi, kemudian kesulitan dalam pemahaman terhadap proses pengerjaan soal, kesulitan dalam menerapkan rumus-rumus matematika dan kesulitan dalam menginterpretasi informasi-informasi yang telah diperoleh.

4. Aspek Mengkomunikasikan

a. Kesulitan siswa berkemampuan matematika tinggi adalah kesulitan dalam menyampaikan dan mentransfer pengetahuannya.

b. Kesulitan siswa berkemampuan matematika sedang adalah kesulitan dalam mentransfer pengetahuan

c. Kesulitan siswa berkemampuan rendah adalah sulit dalam menyajikan dan menyampaikan hasil pekerjaannya baik itu berupa gambar maupun berupa simbol.

5. Perbedaan Kesulitan Siswa Dalam Pembelajaran Matematika dengan Pendekatan Saintifik Ditinjau dari Kemampuan Belajar adalah

a. Aspek Mengamati

Perbedaan mendasar dari siswa yang berkemampuan matematika tinggi, sedang dan rendah dalam aspek mengamati adalah kemampuan dalam memahami simbol-simbol matematika, siswa berkemampuan sedang dan rendah cenderung tidak mengetahui dan mengenal atau bisa membaca simbolsimbol yang ada pada objek yang mereka amati.

b. Aspek Menanya

Perbedaan mendasar dari ketiga subjek berkemampuan matematika tinggi, sedang dan rendah dalam aspek menanya adalah level atau tingkatan pertanyaan yang mereka ajukan. Siswa berkemampuan matematika tinggi cenderung lebih bisa mengajukan pertanyaan lebih tinggi di tingkat pengetahuan dibanding dengan siswa berkamampuan matematika sedang yang hanya bisa mengajukan pertanyan di 
tingkat pertanyaan pemahaman, sedangkan siswa berkemampuan matematika rendah sama sekali tidak bisa mengajukan sebuah pertanyaan.

c. Aspek Mengumpulkan Informasi dan Menalar

Perbedaan mendasar dari ketiga subjek berkemampuan matematika tinggi, sedang dan rendah dalam aspek mengumpulkan informasi dan menalar adalah siswa berkemapuan matematika sedang dan rendah cenderung lebih sulit dalam mengerjakan dan menyelesaikan soal latihan dibanding dengan siswa berkemampuan matematika tinggi. Siswa berkemampuan matematika tinggi tidak mengalami masalah dalam mengerjakan soal latihan yang diberikan.

d. Aspek Mengkomunikasikan

Perbedaan mendasar dari ketiga subjek berkemampuan matematika tinggi, sedang dan rendah dalam aspek mengkomunikasikan adalah siswa berkemampuan matematika tinggi dan sedang cenderung lebih bisa dalam mengkomunikasikan hasil pekerjaannya dibanding dengan siswa berkemampuan matematika rendah yang tidak bisa sama sekali untuk menyajikan hasil pekerjaannnya baik itu berupa gambar maupun simbol-simbol.

\section{DAFTAR PUSTAKA}

Abdurrahman, Mulyono. 2012. Anak Berkesulitan Belajar;Teori, Diagnosis, dan Remediasinya. Jakarta: PT. Rineka Cipta.

A.M. Sardiman. 2013. Interaksi dan Motivasi Belajar Mengajar. Depok: PT. Rajagrafindo Persada.

Depdiknas. 2006. Kurikulum Tingkat Satuan Pendidikan (KTSP)/ Mata Pelajaran Matematika Untuk Toingkat SD/MI. Jakarta: Depdiknas.

Hadi, S. 2001.'Memperkenalkan RME kepada Guru SLTP di Yogyakarta". Makalah disajikan pada Seminar Nasional Realistic Mathematic Education (RME) di Unesa tanggal 24 Pebruari 2001.

Hudoyo, Herman. 1994. Peran Matematika dalam Pengembangan IPTEK dan Penerapan Pembelajarannya di Sekolah. Makalah disampaikan pada seminar regional pembelajaran MIPA dan pelaksanaannya dalam kurikulum SMU 1994 tgl 26 Nopember 1994. Malang.

Hosnan, M. 2014. Pendekatan Saintifik dan Kontekstual dalam Pembelajaran Abad 21. Bogor: Ghalia Indonesia.

Jamaris, Martini. 2014. Kesulitan Belajar; Perspektif, Assessmen, dan Penanggulangannya. Bogor: Ghalia Indonesia.

Kemendikbud. 2013. Pengembangan Kurikulum 2013. Paparan Mendikbud dalam Sosialisasi Kurikulum 2013. Jakarta :Kemendikbud.

Kemendikbud. 2014. salinan lampiran permendikbud republik indonesia nomor 103 tahun 2014. Jakarta :Kemendikbud.

Purwanto, M. Ngalim. 2006. Prinsip-Prinsip dan Teknik Evaluasi Pengajaran. Bandung : PT Remaja Rosdakarya.

Russeffendi. 1988. Dasar-Dasar Matematika Modern. Bandung: Transito.

Rusli. 2006. Studi Keterlaksanaan Penilaian Hasil Belajar Matematika dan Hambatannya Dalam Implementasi Kurikulum Berbasis Kompetensi di SMA Negeri 1 Takalar. Tesis. Tidak Diterbitkan. Makassar: Universitas Negeri Makassar.

Sani, R. A. 2014. Pembelajaran Saintifik; Untuk Implementasi Kurikulum 2013. Jakarta: Bumi Aksara.

Soedjadi, R. 1999. Kiat Pendidikan Matematika di Indonesia. Jakarta: Depdiknas.

Sugiyono. 2006. Penelitian Kuantitatif, Kualitatif, Dan R\&D. Bandung: Alfabeta. 